\title{
An Evaluation of Prospective Engineers' Perceptions on Internships of Engineering Education: A Case Study in Turkey
}

\author{
Oktay C. ADIGUZEL*
}

\begin{abstract}
Internship is vital in engineering education for prospective students, university, and industrial companies since the outcomes of the internship process influence all these agencies. Therefore, the purpose of this study is to examine the perceptions of the prospective engineers on internship in which they are involved during their education. By using the procedures of the qualitative research method, data were collected through semi-structured interviews. The results indicated that prospective engineers focused on the problems in the areas of legal and structural regulations for industrial education, in the theoretical education process given prior to industrial education, and in the structure of enterprises. Based on the problems identified by prospective engineers, the author discusses the cooperation between universities and industry and eventually presents a perspective on how to establish educational partnership structures between universities and the industry for the purpose of improving engineering education.
\end{abstract}

Key-Words: Higher education system; Industrial placement; Engineering education; Internships.

* Assist.Prof. Dr., Anadolu University, Faculty of Education, ocadiguzel@ anadolu.edu.tr 


\section{An Evaluation of Prospective Engineers' Perceptions on}

Internships of Engineering Education: A Case Study in Turkey

\section{Oktay C. ADIGÜZEL*}

ÖZ: Bu çalışmada, mühendislik eğitiminde niteliğin artırılmasında, üniversite-sanayi işbirliğinin öğrenci görüşleri doğrultusunda değerlendirilmesi amaçlanmıştır. Çalışma, tarama türü bir araştırmadan oluşup, var olan durumu belirlemek için veri toplama yöntemlerinden nitel araştırma yöntemlerinden olan yar1yapılandırılmış görüşmeler yoluyla gerçekleştirilmiştir. Çalışma sonucunda, endüstriyel eğitime yönelik yasal ve yapısal düzenlemelerin yetersizliğinden, endüstriyel eğitim öncesi sürecin işleyişinden ve endüstriyel eğitim süresince işverenden ve işletme yapısından kaynaklanan alanlarda sorunların oluştuğu tespit edilmiştir. Çalı̧̧mada, tespit edilen bu sorunlar doğrultusunda, üniversite-sanayi işbirliği tartışlarak, mühendislik eğitiminin geliştirilmesi kapsamında üniversite-sanayi arasında eğitim ortaklık yapılarının nasıl oluşturulması gerektiği konusunda bir perspektif sunulması amaçlanmıştır.

Anahtar Kelimeler: Sanayi Ortaklı Eğitim, Üniversite Sanayi İşbirliği, Mühendislik eğitimi.

* Yrd. Doç.Dr., Anadolu Üniversitesi, Eğitim Fakültesi, Eğitim Programları ve Öğretim Ana Bilim Dalı, ocadiguzel@anadolu.edu.tr 


\section{BACKGROUND}

Rapid developments in the field of information and communication technologies (ICT), easy access to information and easy share of the information obtained, the spread of multi-cultured, multi-language and multi-national companies cause significant transformations in social life and in business areas. Given the competition in the global economy, skill development has become a major issue for many countries (M. Lai and L.N.K. Lo, 2008). The ability of a country to compete with the developed countries in the global world market by adapting itself to these transformations depends on the duration and quality of education that the country provides for individuals. The quality and the duration of education also play an important role in a country's training the qualified workforce necessary for a more powerful economy and for the rapid development of the society. Considering the growth rate of today's technology, one of the important areas of training qualified workforce is engineering sciences at higher-education level.

The rapid developments in technology and science change the profile of today's engineers. Therefore, it is a necessity for those taking engineering education to have sufficient knowledge and applied experience in their fields for the quality and reliability of the services they provide. In this respect, the structures of university-industry cooperation are of great importance in terms of engineering education. On the other hand, the structures of universityindustry cooperation to be established for educational purposes have not been developed adequately in Turkey yet.

Although there are several on-going studies conducted by universities and industrial institutions together in the present system, these studies are mostly carried out in such basic areas of purchase of services as testmeasurement services, expert opinion, scientific publication, problem analysis, improvement of human-machine systems at micro level, and quality-related problem solving (Özok, 2006). Civan and Demireli, (2004) conducted interviews with the representatives of industry and reported that representatives stated various reasons why the educational partnerships between universities and industry have not been adequately developed. Among these reasons are legal and structural loopholes, bureaucratic barriers, communication gap between faculty members at universities, university faculty members' lack of time to meet employers, and monetary demands of working capital establishments found in universities. Hence, the contributions of industry to the improvement of the quality of higher education in Turkey are limited today. In fact, Turkey is one of the biggest countries in the region with its population of approximately 73 million people and with its $17^{\text {th }}$ largest economy in the world. Turkey aims at having 
a more powerful economy in the next ten years and increasing the per capita of gross national product. Therefore, Turkey needs to improve its education system according to the conditions of modern age so that the country can keep and increase its power to compete internationally in this technological and global world. In this respect, the future of university-industry cooperation is of great significance for the improvement of the quality of higher education.

In Turkey, in general, engineering schools provides a five year education first year of which is to improve students' English language proficiency. Students who want to attend engineering schools after finishing their high school education which lasts 12 years are required to be successful in the Higher Education Entrance Exam carried out once in a year. According to their score types of the related area, students who succeed in the exam are centrally placed in one of the engineering programmes they have chosen. As of 2005-2006, 30.857 students in the public universities and 4.956 students in the private universities began their engineering education in Turkey.

In the present system in Turkey, educational partnerships established with industry for engineering education are carried out in the period of time when students are on vacation. During this period, via internships, students go to industrial institutions for educational purposes and try to discover the practical areas to apply their theoretical knowledge. In order for students attending engineering schools to get their engineering degrees, they are supposed to complete this internship in a certain period on certain subjects at the industrial institutions approved by the university. These internships are not credited in engineering education programs, yet they are one of the requirements of an engineering degree. Students are given limited information regarding the internships, also not paid, and their social securities are not covered during internships. Although internships differ from one university to another and from one department to another in terms of application and evaluation, they are similar with respect to specifications, purpose, and method (Kurban \& Şenel, 2006). In addition, subjects of internships also differ from one department to another. The duration of internships are determined as 60 business days for a 4-year educational period, and the planning of this duration depends on the departments. Internships can be carried out in one or more industrial institutions either during the summer season or between the two terms of the academic year. At the end of the internships, students are required to prepare a practicaltraining portfolio that includes their daily-works in the enterprises, and they are supposed to submit this portfolio to the practical-training commissions 
established by the departments. The departments, if they wish so, may also require their students to make presentations regarding their internships.

The process of internship in Turkey, basically aims at helping students know about the business world, obtain information about the working areas of their profession, and learn the application areas of their theoretical knowledge. The duration of this process and its way of execution, differ from those of the universities in developed and industrialized countries. The educational programs of engineering schools in such countries as United States of America, Canada, England, Germany and France are shaped on the basis of educational partnerships with the industry (Serbest \& Mandal, 2006). The close co-operation between universities and industry is also one of the fundamental strengths of the engineering education in Finland. Finnish engineering students have on average 23 months of working experience, when they finish the Master's program (The Finnish Association of Graduate Engineers, 2004 in Korhonen-Yrjänheikki et al.,2007)

In order for the education model of university-industry partnership to work effectively, it is vital that a healthy communication should be established between universities and industrial institutions regarding not only the goals of the educational program but also the planning and execution of the application process as well. It has been claimed, moreover, that higher education (HE) institutions derive significant advantages from sending students on work placements (R. Bennett et al., 2008). According to Arnold et al. (1999), the employer's contribution to the intellectual development of the individual student may be substantial in view of the fact that academic courses on vocational degrees cannot teach all the competences needed for a career in a particular field (Bennett et al, 2008).

In order for Turkey to adapt itself to the developments in science and technology and to the new conditions caused by globalization, it is a necessity today to support educational partnerships to be established between universities and industry. However a majority of the representatives of industrial institutions in Turkey state that what is taught to candidate engineers in today's education system does not match the expectations of the industry at all (Aytekin 2006). The main goal of universities in training students of engineering is to have them see the application areas of their theoretical knowledge, learn information about the business world and acquire industrial discipline. On the other hand, employers expect engineering students to have such skills as problem solving, taking responsibilities, working in groups, following recent developments in the field, being creative, and being an effective leader and manager (Beysel, 2005). 
University-industry partnership is also important for Turkey to improve the university-industry relationships for the process of integration with the European Union. The commission report of "Future Concrete Goals of Education Systems" prepared by the European Union Directorate-General for Education and Culture on January 31, 2001, emphasized the need for the establishment of relationships between the educational institutions and industry. The report also suggested that educational institutions should benefit from the relationships established with the local enterprises in order to facilitate the process of employment and to organize educational programs in line with future needs (Ministry of National Education-MNE, 2006). In addition, following the "Conference of European Ministers of Education" held in Vienna on 16-17 March, 2006, it was recommended that higher education institutions maintain cooperation with industry in educational studies. At the conference, it was also suggested that special supplementary programs be developed for increasing the cooperational opportunities for applied studies between higher education institutions in the region as well as for the purpose of developing technology-based small-scale and middlescale enterprises (MNE, 2006). Studies carried out on this issue in the area of higher education in Turkey indicate that an educational partnership still has not been established in a real sense between the universities and industry. In addition, "Higher Education Strategy of Turkey" was prepared by Higher Education Council in Turkey in February of 2007 disseminated a report pointing out the necessity for redesigning the educational partnerships to be established between the universities and industry. This report also included strong statements regarding the development of cooperational structures between the universities and industry; however, there were not enough concrete suggestions about how to establish these relationships. Besides these, it is reported that industrial education suffers from a variety of problems. Therefore, the purpose of this study is to explore these problems through getting perceptions of prospective engineers on internships, which is the starting point of the cooperation between university and industry. For this purpose, the study basically seeks answers to the issues of what difficulties prospective engineers experience in industrial education given by university-industry partnership and propose recommendations regarding these issues to improve the quality of the industrial education given by university-industry partnership. 


\section{METHOD}

\section{Participants}

Participants included twenty-one prospective engineers (junior students at engineering education) attending the Faculty of Engineering and Architecture at one of the largest universities in Turkey. Nine of them were female while twelve were male. On voluntary basis, three prospective engineers from each of the various programs (Computer Engineering, Environmental Engineering, Electrical and Electronics Engineering, Industrial Engineering, Civil Engineering, Chemical Engineering, and Materials Science and Engineering) were involved. Table 1 shows the number of participants across the departments. At the study conducted, all participants had internship experience.

Table 1. Participants

\begin{tabular}{lll}
\hline Participants & Code & $N$ \\
\hline Civil Engineering & Sci & 3 \\
Electrical and Electronics Engineering & Sel & 3 \\
Material Science and Engineering & Sma & 3 \\
Chemical Engineering & Sch & 3 \\
Environmental Engineering & Sen & 3 \\
Industrial Engineering & Sin & 3 \\
Computer Engineering & Sce & 3 \\
Total & & 21 \\
\hline
\end{tabular}

\section{Research Model and Data Collection}

The present descriptive study was conducted by following the principles of qualitative research. Among the data collection methods of qualitative research, semi-structured interviews were used to gather the perceptions of the participants. The semi-structured interviews were held in a way that the interviewer previously prepared the basic questions related to the interview subjects, asked these questions during the interview and, when necessary, directed other questions in order to further clarify and elaborate the answers. The interviews lasted 25-35 minutes on average, and all the interviews were audio-recorded. During the interviews, several questions were directed on 
the issue of "information about the structure and content of the industrial education organization". For this issue, the following questions were asked: Before industrial education: "Is there a preparation process for industrial education?", "Which criteria are taken into consideration for the appropriateness of the enterprises chosen?", "Which documents are prepared for education to be given in the enterprises?", "How are students informed about the process prior to education?"; During industrial education: "Which activities completed in the enterprise during industrial education?", "Who guide students in the enterprises during industrial education?", "How and by whom are the expenditures of students met during industrial education (transportation, eating etc.)?", and "How and by whom is the appropriateness of the works to the predetermined goals controlled in the work place?" Then, the question focused on the problems related to the administration and planning of industrial education (Related to the industrial education, what are the problems you come across before the education, during the education and after the education?) took place.

\section{The Analysis of the Semi-structured Interviews}

As stated in qualitative research literature (Blanchet \& Gotman, 2001; Yıldırım \& Şimşek, 2005), descriptive analysis of data gathered through semi-structured interviews was run as follows: (1) All the interviews were transcribed, (2) Depending on the data obtained and considering the related literature and the conceptual framework, a thematic frame was formed and the themes determined were assigned codes, (3) In line with the thematic frame, the data were read and the frequencies of the themes were found. The themes determined were classified under main headings. In this phase, for the reliability of the thematic frame formed and of the data, two field experts who are knowledgeable about qualitative research were consulted, and (4) the results were supported by direct quotations

\section{RESULTS AND DISCUSSIONS}

The analysis of the semi-structured interviews revealed that prospective engineers point out the issues (problems) they experience in industrial education given by university-industry partnership. Three main themes were determined regarding the issues in industrial education stated by participants. These themes included: (1) the issues that result from the employers; (2) the issues that result from the lack of legal and structural regulations in industrial education, and (3) the issues that result from the process prior to industrial education. 
Table 2. Issues regarding the industrial education and their frequencies according to departments of engineering school

\begin{tabular}{llllllllll}
\hline Students & & $\begin{array}{l}\text { Issues that } \\
\text { result from } \\
\text { the } \\
\text { employers }\end{array}$ & $\begin{array}{l}\text { Issues that result from } \\
\text { the lack of legal and } \\
\text { structural regulation } \\
\text { in industrial education }\end{array}$ & $\begin{array}{l}\text { Issues that } \\
\text { result from the } \\
\text { process prior } \\
\text { to industrial } \\
\text { education }\end{array}$ & Total & \\
\hline Code & $N$ & $f$ & $\%$ & $f$ & $\%$ & $f$ & $\%$ & $f$ & $\%$ \\
Sci & 3 & 7 & 39 & 7 & 39 & 4 & 22 & 18 & 100 \\
Sel & 3 & 10 & 50 & 7 & 35 & 3 & 15 & 20 & 100 \\
Sma & 3 & 7 & 37 & 7 & 37 & 5 & 26 & 19 & 100 \\
Sch & 3 & 9 & 39 & 5 & 22 & 9 & 39 & 23 & 100 \\
Sen & 3 & 8 & 57 & 4 & 29 & 2 & 14 & 14 & 100 \\
Sin & 3 & 10 & 50 & 5 & 25 & 5 & 25 & 20 & 100 \\
Sce & 3 & 8 & 50 & 4 & 25 & 4 & 25 & 16 & 100 \\
Total/21 & 59 & 45 & 39 & 30 & 32 & 25 & 130 & 100 \\
\hline
\end{tabular}

* Frequencies show the number of each issue (Each student could give opinion about more than one problem) occurred in student's views

As seen at Table 2, during the interviews, participant prospective engineers focused on three mains themes by stating a total of 130 statements pointing out these themes. Of 130 statements, $59(45 \%)$ were regarding the issues that result from the employers while $39(30 \%)$ were related to the lack of legal and structural regulation in industrial education. Only $32(25 \%)$ were associated with issues that result from the process prior to industrial education.

Based on the perceptions of participants for each theme, sub-themes were formed, and the related frequency-values were found.

\section{Issues that result from the employer during industrial education}

The analysis of the interviews held with prospective engineers demonstrated that the problems experienced during industrial education mostly resulted from the employer. Out of 130 statements, 59 (45\%) were related to this issue. Further analysis of this issue based on statements made by participants was conducted to explore this issue in depth. Five main subissues were identified (Table 3). 
Table 3. Distributions of sub-issues of the issues that result from the employer during industrial education

Issues that result from the employer during industrial education $\quad n * / 21 \quad \%$

a- The enterprises did not define the duties of students, and the

students were not given enough responsibilities during 18

$18 \quad 31$

internship

b- Insufficient guidance in the enterprises

$16 \quad 27$

c- Lack of responsible persons for education in the enterprises

d- The duties given by the employer were not relevant to the

area of education

$6 \quad 10$

e- Gender discrimination in the enterprises during internship

* Number of students who view sub-themes as a problem (Each student could express his opinion about more than one problem).

As illustrated in Table 3, the analysis of the sub-issues revealed that a majority of the students (18 out of 21) stated that their duties were not defined and they were not given enough responsibilities in the enterprises. The students also reported that this issue occurred for several reasons such as the limited time they spent in the enterprises, lack of insurance for industrial accidents, lack of appropriate structures of enterprises for education, and indifferent attitudes of employers. Some of these views are presented below:

[Sel2- "My duties were not clear. During the time I was there in the enterprise, I did whatever they wanted me to do so. In fact, these were not related to my job. I looked at the projects and saw how they drew the projects."] 
[Sen2- "We experienced some problems with engineers where I did my internship. We didn't have close relationships with them. They didn't want us to do anything related to their job, so we were only observers in the enterprises. We wandered around and tried to learn about the places of environmental engineering. They talked to us, and we listened to them."]

During the interviews, sixteen participants (27\%) reported that they were not guided enough in the enterprises during their industrial education whereas fourteen $(24 \%)$ participants mentioned the lack of a person responsible for industrial education and added that they requested help from the employees in the enterprise about the issues they had difficulty with. One of the views stated by the participants was as follow:

[Sel3- "There was nobody to guide me. All the employees working in the enterprise tried to help me."]

Six participants $(10 \%)$ stated that what the employers wanted them to do was irrelevant to their field of education. Some of the participants reported that they were asked to do such duties as carrying materials from the warehouse, following the signature process of documents and files, transferring the reports to the electronic environment and answering the phones. Some of these views are presented below:

[Sell- "I had to do things irrelevant to my job in the enterprise. I did the business inventory staff and spent a lot of time organizing the files. I helped the workers in the production department when they needed. I did a lot of things irrelevant to my job."]

[Sce2- "I am an expert on software, but I did many things that were not related to my job. For example, computer keyboards; I had to find out the faulty keys pressing all of them one by one the whole day. I checked a bag of flash-disks in a day to see if there was any problem with them. I even had to carry monitors from the warehouse."]

During the interviews, the male students did not mention any gender discrimination in the enterprises, yet five of the female students interviewed reported that they experienced this problem. These students stated that there was a male-dominant environment in the enterprises and added that they were not given enough responsibilities in the enterprises because of their gender. Two of the views stated by the participants were as follow: 
[Sma-1-"As a female person, I sometimes caused problems there just because there were a few female workers in the enterprise. Sometimes, people did not comfortably and freely talk about things as they wanted. The workers in the iron foundry were surprised to see girls there. When I asked them why, they told me not to damage our nail-polish. These problems mostly occurred due to the workers. "]

[Sel-3-"I was the only female person in the department where I worked in the enterprise. Some were congenial to me, but some were not probably because of my gender. They found it strange to see me there."]

When we consider the results, it seems that problems related to employers are the main themes of prospective engineers during the internships. However, to interpret that the issues or problems stated by participants result from companies is not a right approach to consider. The lack of cooperation between university and industry on assessment, planning, and follow-up of internships play vital role on this matter. Results of studies conducted by Adiguzel (2008), Aytekin (2006), and Özok (2006) on cooperation between university and industry point out that bureaucratic problems and lack of communication are two main issues arising on the process of cooperation.

Issues that result from the lack of legal and structural regulations for industrial education

The issues that result from the lack of legal and structural regulations for this educational process were the second main issue stated by the participants. Out of 130 statements, 39 (30\%) statements were regarding this issue. Further analysis of this issue based on statements made by participants was conducted to explore this issue in depth. Three main sub-issues were identified (Table 4). 
Table 4. Distribution of sub-issues that result from the lack of legal and structural regulations for industrial education

$\begin{aligned} & \text { Issues that result from the lack of legal and structural } \\ & \text { regulations for industrial education }\end{aligned}$
$\begin{aligned} & \text { a- The lack of legal regulations related to the } \\ & \text { accommodation and transportation needs of students and } \\ & \text { to the insurance of health and accident }\end{aligned}$
b- The lack of regulations regarding the acceptance of
students by enterprises
c- The lack of regulations for the appropriateness of
enterprises to industrial education

* Number of students who view sub-themes as a problem (Each student could express his opinion about more than one problem).

As illustrated in Table 4, the majority of the participants (16 out of 21) reported that their insurance premiums for health and industrial accidents in the enterprise were not paid; and that due to security matters, they were not given the duties that require responsibilities and thus they did nothing but observations in the enterprise. The students also pointed out that it was the enterprise who took decisions on the issues of transportation and accommodation. Some of the participants discussed these issues as follow:

[Sci-2- "We didn't have any social security. They didn't help us with insurance, meals, transportation, or accommodation. Actually, we didn't expect them to do so."']

[Sma-1- "To me, it was no use doing internship. They weren't interested much in us. They wanted us to sit down somewhere. Also, it was a dangerous place. They didn't want to give us any duty because we didn't have any insurance."] 
As a result of the interviews, it was found out that the enterprises did not have any regulations prepared by the university-industry partnership for the acceptance of students. During the interviews, most of the students stated that their university did not help them find an enterprise appropriate for industrial education. Some of the participants discussed these issues as follow:

[Sin-3- "We were left alone to find a place for internship. There was no communication between the enterprise and the university. We only sent a document for acceptance and submitted a report when we returned. That's all. "]

[Sel-1- "Our department does not give much importance to internship, so I didn't have any written documents in hand."]

Issues that result from the lack of legal and structural regulations for industrial education have been mentioned in previous studies (Adiguzel, 2008; Aytekin, 2006; Özok, 2006). The results of these studies are parallel with our findings stated above. It can be interpreted that lack of encouragement strategies and lack of national structural regulations are main resources of the issues mentioned above and stated by prospective engineers.

\section{The issues that result from the process prior to industrial education}

The analysis of the interviews indicated that some issues that resulted from the process prior to industrial education are problems for prospective engineers. Thirty-two out of 130 statements were regarding this issue. Further analysis of this issue based on statements made by participants was conducted to explore this issue in depth. Three main sub-issues were identified (Table 5). 
Table 5. Distribution of sub-issues that result from the process prior to industrial education

Issues that result from the process prior to industrial education $\mathrm{n} * / 21 \quad \%$

a- The employers were not informed about the educational

backgrounds of students and about the content of education

$15 \quad 47$

b- The students did not have clear expectations about the educational process in the enterprises

c- The students were not well-informed about the goals of industrial education.

* Number of students who view sub-themes as a problem (Each student could express his opinion about more than one problem).

As can be seen in Table 5, majority of the students (15 out of 21) pointed out that the employers did not have information about the scope of industrial education and about their educational backgrounds and that the employers did not ever attempt to learn about these issues. The students also stated that this situation causing the university and the enterprise to have different expectations influenced the educational process negatively. One of the views stated by the participants was as follows:

[Sci-2-Most of the enterprises in the area of construction did not have much information about internship. Thus the enterprises did not have close relationships with us.]

The interviews held with the students revealed that most of the students did not have clear expectations for the educational process in the enterprises. During the interviews, many of the students reported that they went to the enterprises because it was obligatory and that their main goal was to discover the business world. When the students were directed the question of whether they were adequately informed about the goals of industrial education by the university, most of them gave negative responses to this question. One of the views stated by the participants was as follow: 
[Sci-1- "I didn't go to the enterprise with an expectation. I was anxious mostly about the process. That was, I didn't know what I would do. I always wondered about how it would be. I didn't know what would happen or how I would do it."']

When we discuss prospective engineers' perspectives, it seems that lack of planning before internships reduce the effectiveness of internships. In addition, lack of providing information to interns about their internships and lack of coordination between interns and companies influence negatively the outcomes of the process of internships.

\section{RECOMMENDATIONS}

Based on the results and discussion, the author offer following suggestions to the issues or problems stated by the participants in order to improve the quality of the process of internship, main bridge or starting point of cooperation between university and industry.

In order for industrial education to be effective, first of all, it is necessary to make some legal and structural regulations at national level. When the difficulty experienced by students in finding an enterprise for internship is considered, there should be necessary regulations for the employment of students proportional to the number of employees in the enterprises for educational purposes. Moreover, the employers should be encouraged to accept students through tax reductions for enterprises. Also, in order for students to undertake more active duties in the enterprises, the necessary regulations should be made regarding the payment of students' insurance premiums for occupational hazards. For the purpose of helping students take their industrial education in a city of their choice, their needs for accommodation and transportation should be met by state institutions and/or by enterprises. Furthermore, the enterprises should meet and document certain criteria to accept students for internship.

For the effectiveness of industrial education that covers a short period of time, a coordinating structure should be established to prepare and guide the students for this process, to classify the enterprises in terms of their business areas, to establish communication between the enterprises and the students and to inspect the appropriateness of industrial education in enterprises to the goals of industrial education. Students should be informed orally and in writing through documents prepared in line with the goals of industrial education by the coordinating structure. Prior to industrial education, meetings should be organized between faculty and the employers 
in order to negotiate the goals of industrial education, the definition of student duties and the evaluation of students.

This study has revealed that not enough importance is given to industrial education in enterprises; that there are no preparations for the process of industrial education; and that there is no structure for such education in enterprises. In order to develop the instructional features of industrial education, it is quite important that there is a strong communication between the enterprises and universities; that students be given responsibilities in the enterprises; and that they participate in the project groups. Crebert et al. (2004) cited 'learning to work in teams' and 'being able to accept responsibility' as major benefits arising from work placements because team activities and the assumption of responsibility were instrumental in developing critical thinking, the capacity to make decisions, persuasion, cooperation, ethical awareness, and several other occupationally valuable competences (R. Bennetta et al.,2008). For that, students should work in the areas in line with their educational fields, and they should be involved in active production rather than only acting as observers in the enterprises. For this purpose, it is important that enterprises regard the students as their future employees and act accordingly.

Industrial education should be redesigned on project-basis in line with bilateral agreements between the enterprises and universities. In order for students to know the business world better and to become knowledgeable about the areas of their profession, students, as they do in the present system, should have the right to take industrial education in their first three years of education in different enterprises which have a functional coordinating structure. Following this process, which aims at helping students know the business world and gain self-confidence, students should take part in the projects to be developed by the university-industry partnership and should spend their last year of educational period between the university and enterprises so that they can learn theoretical and applied information about the specialization areas they will choose. This will provide students with the opportunity for specialization as well as will enable them to work in the enterprises when they graduate. Thus, such a regulation will facilitate the employment of students in enterprises and will also shorten the duration of students' adaptation to the enterprise. 


\section{Limitations}

The results of the current study should be interpreted by considering the following limitation. In the scope of the study, the fact that the qualitative data gathered through the interviews held with a limited number of students from the same university. However, the issues revealed in the result of this study are supported by the findings of studies found in the literature. It is believed that this qualitative study can be considered a base study for further both qualitative and quantitative studies that would be conducted with more participants, different settings and various data collection methods. This will help to extend the knowledge-base of the topic covered in the present study.

\section{REFERENCES}

Adiguzel, O. C. (2008). An evaluation of industrial placement in engineering programmes: a case in Turkey. European Journal of Engineering Education, , $\underline{33}(\underline{1)}, 33-43$.

Arnold, J., J. Loan-Clarke, A. Harrington, and C. Hart. (1999).Students' perceptions of competence development in undergraduate business-related degrees. Studies in Higher Education, 24(1), 43-59 In R. Bennetta, L. Eagleb, W. Mousleyc and R. A. Choudhurya. Reassessing the value of work-experience placements in the context of widening participation in higher education Journal of Vocational Education and Training, 2008, 60(2), 105-122.

Aytekin M. (2006). Mühendislik eğitiminden beklenenler [Expectations from engineering education]. This is a paper presented at a conference, II. National Engineering Congress of Turkey, 121-128.

Beysel, C. (2005). A businessman's perspective of engineering training in Turkey and what is expected from an engineer. This is a paper presented at a conference, in European Society for Engineering Education (SEFI), 19-30

Blanchet, A., Gotman, A. (2001). L'enquête et ses méthodes de l'entretien, (Nathan Université: Paris)

Bennetta, R., Eagleb, L., Mousleyc, W. and Choudhurya R. A. (2008). Reassessing the value of work-experience placements in the context of widening participation in higher education Journal of Vocational Education and Training, 60(2), 105-122.

Civan, M. \& Demireli, C. (2004). Sanayi işletmelerinde eğitim ve üniversite sanayi işbirliği arayışı üzerine bir uygulama. [Education in industrial enterprises and a study on university-industry cooperation].This is a paper presented at a conference I. National Engineering Congress of Turkey, 243-252

Kurban M., \& Şenel, M. (2006). Mühendislik eğitiminin sanayiye açılan penceresi: Staj. [Window of engineering education to the industry: Internship]. This is a paper presented at a conference, II. National Engineering Congress of Turkey, 289-294. 
Lai M. and. Lo L.N.K. (2008). Perceived workplace competences at three sites on the Chinese Journal of Vocational Education and Training, 60(2), 189-204

Ministry of National Education (2007), Retrieved November, 12, from http://www.meb.gov.tr

Özok A.F. (2006).Üniversite-Sanayi ilişkilerinin etkinleştirilmesi.[Activating university-industry relationships] This is a paper presented at a conference, II. National Engineering Congress of Turkey, 57-61.

Serbest, A.H. \& Mandal, H. (2006). Üniversite-Sanayi İşbirliğinin Geliştirilmesi için Eğitim Sistemi içinde uygulanabilecek öneriler [Propositions for development cooperation between University and Industry]. This is a paper presented at a conference, II. National Engineering Congress of Turkey, 269278

Tezok F., Simsek, S., Altay, A., Gokalp, E. (2005). The difficulties new graduates face in the industry. This is a paper presented at a conference, European Society for Engineering Education (SEFI), 542-546.

Yıldırım, A., Şimşek H. (2005). Qualitative Research Methods in Social Sciences, (Edition Seckin: Ankara)

The Finnish Association of Graduate Engineers (2004) in K. Korhonen-Yrjänheikki, T. Tukiainen and M. Takala. New challenging approaches to engineering education: enhancing university-industry co-operation, European Journal of Engineering Education, 2007 32(2), 167 - 179.

Crebert G., Bates M., Bell B., Patrick C. and Cragnolini V. (2004). Developing generic skills at university during work placement and in employment: Graduates' perceptions. Higher Education Research and Development, 23 (2), 147-165. In R. Bennetta, L. Eagleb, W. Mousleyc and R. A. Choudhurya. Reassessing the value of work-experience placements in the context of widening participation in higher education Journal of Vocational Education and Training, 2008, 60(2), 105-122.

\section{About the Author}

Following his bachelor's degree, the author got his M.A. and Ph.D. in Educational Science at the Ecole Normale Supérieure de Cachan in France. The author is currently an assistant professor of curriculum and development in education at the department of educational science of Education Faculty at Anadolu University in Turkey.

Correspondence concerning this article should be addressed to Assist. Prof. Oktay C. Adiguzel, the Division of Curriculum and Development in Education, Education Faculty, Anadolu University, Yunus Emre Campus, 26470, Eskisehir, TURKEY. 


\section{ÖZET}

Amaç ve Önem: Türkiye'nin bilim ve teknoloji alanındaki yeniliklere ve küreselleşmenin getirmiş olduğu yeni şartlara uyum sağlayabilmesi için, üniversite ve sanayi işbirliğince oluşturulacak olan eğitim ortaklıklarını desteklemesi günümüz koşullarında bir gereklilik haline gelmiştir. Günümüz teknolojisinin ilerleme hızı dikkate alındığında, nitelikli işgücünün yetiştirileceği önemli alanlardan biri yükseköğretim düzeyindeki mühendislik bilimleridir. Teknoloji ve bilimde yaşanan hızlı gelişmeler beraberinde mühendis profilini de değiştirmektedir. Dolayısıyla, mühendis adaylarının, alanlarında yeterli uygulama deneyimine ve bilgi birikimine sahip olmaları, verecekleri hizmetin niteliği ve güvenirliliği bakımından bir gerekliliktir. Türkiye'nin Avrupa Birliği'ne entegrasyonunda da üniversite ve sanayi ilişkilerinin geliştirilmesi oldukça önemli bir yer kaplamaktadır. Avrupa Birliği Eğitim ve Kültür Genel Müdürlüğü'nün 31 Ocak 2001 tarihli, "Eğitim Sistemlerinin Gelecekteki Somut Hedefleri” konulu komisyon raporunda eğitim kurumlarının iş dünyası ile ilişkilendirilmesi gereği vurgulanmıştır. Raporda, istihdam sürecinin kolaylaştırılabilmesi ve gelecekteki gereksinimler doğrultusunda eğitim programlarının düzenlenebilmesi için eğitim kurumlarının kendi yerel çevrelerindeki işletmeler ile kurdukları temaslardan yararlanmaları önerilmiştir (MEB, 2006). Yine, Avrupa Birliği Avusturya Dönem Başkanlığı tarafindan 16-17 Mart 2006 tarihlerinde Viyana'da gerçekleştirilen "Eğitim Bakanları Konferansı"nda kabul edilen sonuçlar ve eylem için tavsiye kararlarında yükseköğretim kurumlarının eğitim, araştırmalarda endüstri ile yakın işbirliğine olan bağımlılı̆̆ı vurgulanmıştır. Toplantıda ayrıca, bölgedeki yükseköğretim kurumları arasındaki uygulamalı araştırmada işbirliği firsatlarının ve teknoloji temelli küçük ve orta ölçekli girişimlerinin geliştirilmesi amacıyla özel destek programlarının geliştirilmesi önerilmiştir (MEB, 2006). Tüm bunlara karşın, Türkiye'de ki yükseköğretim alanında gerçekleştirilen çalışmalar, üniversite ve sanayi arasında gerçek anlamda bir eğitim ortaklık yapısının henüz oluşturulamadığını ortaya koymaktadır. Mühendislik eğitiminde üniversitelerin ve işverenlerin beklentilerine karşılık sürecin temel aktörleri olan öğrenciler üzerine Türkiye'de yeteri kadar çalışma bulunmamaktadır. Çalışmada, mühendislik eğitimini sürdüren öğrencilerin görüşlerine dayalı olarak, üniversite ve sanayi ortaklığında yürütülen eğitimin işleyişi analiz edilmiş ve sürecin etkililiği değerlendirilmiştir.

Yöntem: Araştırma, tarama türü bir araştırma olup, var olan durumu belirlemek için veri toplama yöntemlerinden nitel araştırma yöntemlerinden faydalanılarak yarıyapılandırılmış görüşmeler ile gerçekleştirilmiştir. Araştırma, Eskişehir Anadolu Üniversitesi, Mühendislik-Mimarlık Fakültesi üçüncü sınıf öğrencisi olan dokuzu bayan on ikisi erkek toplam yirmi bir öğrenci ile gerçekleştirilmiştir. Görüşmeler, Bilgisayar Mühendisliği, Çevre Mühendisliği, Elektrik Elektronik Mühendisliği, Endüstri Mühendisliği, İnşaat Mühendisliği, Kimya Mühendisliği, Malzeme Bilimi ve Mühendisliği olmak üzere her programdan gönüllülük esasına dayalı olarak üçer kişi ile gerçekleştirilmiştir.

Bulgular: Yarı yapılandırılmış görüşmeler sonucunda endüstriyel eğitime ilişkin birçok sorun tespit edilmiştir. Bu sorunlara yönelik üç ana tema oluşturulmuştur. Bunlar, (1) endüstriyel eğitime yönelik yasal ve yapısal düzenlemelerin yetersizliğinde kaynaklanan sorunlar; (2) Endüstriyel eğitim öncesi sürecin işleyişinden kaynaklanan sorunlar; (3) Endüstriyel eğitim süresince işverenden ve işletme yapısından kaynaklanan sorunlar olarak sıralandırılmışlardır. Çalışmada tespit edilen bu sorunlar için öneriler geliştirilmiştir. 